УДК 321

DOI: $10.32837 /$ space.v0i11.136

Володимир Миколайович Шаповал

доктор філософських наук, професор, професор кафедри соціально-гуманітарних дисциплін Харківський національний університет внутрішніх справ МВС України, м. Харків, Україна

\title{
МЕТАФІЗИКА ВЛАДИ: КЛАСИЧНИЙ ФІЛОСОФСЬКИЙ ДИСКУРС
}

Анотація. У межах класичної філософської думки було розроблено важливі принципи функціонування влади у суспільстві та засоби, що забезпечують їі ефективність. 3'ясовано, що владні стосунки супроводжують людину як колективну істоту упродовж усієї iii iсторії, є незмінним атрибутом соціального життя. Будучи успадкованими від своїх тваринних предків, вони отримали найрізноманітніші форми у ранніх людських спільнотах, виконуючи як конструктивну, так і деструктивну роль. Вододілом між вказаними проявами влади $\epsilon$ виконання нею своїх головних функцій, серед яких чи на найпершому місці стоїть керування суспільними процесами, забезпечення сталого розвитку людських спільнот. За традицією, владою зі знаком «плюс» називали таку владу, яка приносить благо більшій частині або усім членам певної спільноти. Негативна влада - це така влада, яка має метою благо обмеженого кола обраних або навіть одного верховного правителя, i, у кінцевому підсумку, руйнує соціальну тканину суспільства. Питання щодо співвідношення цілей і засобів, якими влада домагається виконання своїх вимог, має тут вирішальне значення. Класична філософська думка обгрунтовано доводить, що для розумних істот, якими вважають себе люди, більш прийнятними впровадження владних рішень $\epsilon$ не насильство, а моральний авторитет і право. Саме право у такому, що все більш ускладнюється, людському суспільстві, поступово стає пріоритетним інструментом влади. Упродовж майже всієї людської історії можна спостерігати тісний зв'язок між владою і насильством. Іноді здається, що воно взагалі є неусувним 3 людського життя, ледве чи визначальний чинник людських стосунків. Саме по собі насильство мало у кого знаходить відверте схвалення. Більшість філософів, та й взагалі пересічних людей, як правило, його засуджують. Влада завжди прагне зберегти себе як можна довше, у граничному плані стати вічною. Проте є багато причин об'єктивного і суб'єктивного характеру, що ставлять межу таким намаганням. Людське суспільство - це виключно складна система зв'язків і відносин. Ефективна робота цієї системи забезпечується, у тому числі, ефективними управлінськими рішеннями, а також тісним зв'язком між прийнятими рішеннями i ïx виконанням. Тобто, - саме владними відносинами. Хочемо ми цього чи не хочемо, але у суспільстві завжди будуть керівники і підлеглі, ті, хто приймає рішення, i ті, хто повинен їх виконувати, тобто, владарюючі і підвладні. Від того, наскільки будуть ефективними рішення, і наскільки успішно вони будуть впроваджуватись у життя, залежить успішне функціонування різних людських спільнот, майбутнє загальнолюдського суспільства взагалі. Саме це, в ідеальному варіанті, повинна забезпечувати влада.

Ключові слова: влада, філософія влади, владні відносини, метафізика влади.

Проблема влади та владних відносин завжди була актуальною у філософській i політологічній думці. Вона торкається багатьох сторін економічного, політичного, правового і духовно-культурного життя будь-якого суспільства. Влада охоплює своїм впливом усі рівні існування людської спільноти загалом, торкається кожного індивіда, зокрема. «Нам, землянам, - зауважує В.Ф. Халіпов, - людям, що вже у середині XX століття заговорили про свої соціально-культурні феномени і глобальні проблеми, вступаючи у XXI століття, слід на найперше місце ставити владу в усьому різноманітті iii форм і проявів» (Халипов, 1999, с. 14).

Влада $є$ складним, багатовимірним феноменом, що відкриває необмежені можливості для найрізноманітніших тлумачень. Філософи, соціологи, політичні мислителі, правознавці, спеціалісти інших напрямків пропонують різні концепції влади, розробляють іï теоретичні моделі, що потім намагаються втілити на практиці. 
Аналіз сучасної літератури 3 проблем влади показує, що поняття влади наповнюється надзвичайно великим і багатозначним смислом, набуває безлічі відтінків, торкається багатьох потреб і інтересів людей. «Влада, - зазначав Е. Тоффлер, - це здатність і реальна можливість правителів або народу робити радикальний i всеосяжний вплив на діяльність, поведінку, свідомість i помисли людей, розпоряджатися їх долями» (Тоффлер, 2003, с. 13). Разом 3 тим, «3 усіх аспектів нашого життя, влада залишається одним 3 найменш зрозумілих і найбільш важливих особливо для нашого покоління» (Тоффлер, 2003, с. 21).

Намагаючись дати точне визначення влади, Макс Вебер писав, що «Влада (Macht) означає будь-яку можливість проводити усередині соціальних стосунків власну волю, навіть усупереч опору, незалежно від того, на чому така можливість заснована» (Weber, 1922, p. 28). Проте таке тлумачення вимагає певної конкретизації. При абстрактному підході до розуміння влади, зауважує М. М. Кейзеров, «уся увага зосереджена на констатації факту детермінуючої дії однієї сторони відносин на іншу безвідносно до того, в якій сфері це здійснюється» (Кейзеров, 1973, с. 14).

Якщо мати на увазі політичний контекст, то у цьому сенсі влада виступає необхідним інструментом «для узгодження інтересів і дій різних соціальних груп, для підтримки життєдіяльності і збереження цілісності суспільства» (Панарин, 2000, с. 5556).

Зазвичай владою вважається здатність і можливість втілювати свою волю, справляти визначальний вплив на діяльність, поведінку і загалом існування підвладних, використовуючи при цьому всі можливі засоби. Проте, аналіз різноманітних іiі проявів у світі дозволяє максимально широко поглянути на проблему і вийти на метафізичне їі розуміння.

Владу можна віднести до біосоціальних явищ. Дослідження представників конкретних наук показують, що владні відносини люди отримали у спадок від своїх мавпоподібних предків. Якщо проаналізувати стосунки у тваринному світі, то можна побачити, що колективні тварини завжди живуть у певних ієрархічних структурах і на вершині кожної ієрархії стоїть найавторитетніша тварина - вожак, - що має повну владу над тими, хто стоїть нижче нього. Вожаком він стає, завдяки своїй силі, досвіду та вмінню керувати підлеглими, несвідомо додержуючись закону: головне - це благо цілого, тобто, зграї. Становище того, хто має найвищу владу, є нестійким і тимчасовим. Головним він перебуває недовго. Через силу силенну випадкових причин він поступається місцем наступному претенденту. Можна впевнено сказати, що ієрархічні стосунки та влада одних тварин над іншими у тваринному світі $є$ одним з цінних еволюційних надбань природи. Завдяки цьому колективні тварини діють набагато успішніше і мають шанс існувати набагато довше, аніж одинаки. У природному світі діють суворі закони виживання найсильніших, найбільш пристосованих, що створює ситуацію, коли кожне наступне покоління є кращим попереднього, а існування виду може продовжуватись тисячі мільйонів років.

Оскільки люди з самого початку були колективними істотами, владні стосунки супроводжували їх на протязі всієї їх історії. У первісному родовому суспільстві, коли люди були рівними, влада вождів базувалась на їх фізичних і інтелектуальних якостях i багато у чому була подібна до стосунків у звіриній зграї. Вожак примушував підкорятись інших членів первісного людського стада, завдяки своїй фізичній силі, а за непокору чекала жорстока розплата. Пізніше стосунки стали більш людянішими i вождя почали вибирати всі дорослі члени роду за його високий моральний авторитет. Не випадково родоплемінні відносини, що мали місце за первісної доби, називають первісною демократією. 
3 появою у суспільстві соціальної та економічної нерівності, розшарування людей на заможних і незаможних, виникли вкрай різноманітні і суперечливі інтереси. Як наслідок, владні стосунки надзвичайно ускладнились. Цілком очевидно, що влада почала концентруватись у руках небагатьох, економічно домінуючих особистостей, та у той час як більшість людей чи людських спільнот перебувала у ролі тих, хто повинен був частково чи повністю підкорятись, аж до того, що владарі вирішували, жити їм чи померти.

До того, як відбулось розшарування на певні стани або класи, влада носила суспільний характер, не було потреби у примусових установах, особливому апараті насилля і спеціальних людях, які виконували ці функції. У класовому суспільстві відчуження основної маси людей від влади перетворилось у норму життя, незалежно від форм державного устрою. 3 появою приватної власності, класів і держави кровні зв'язки руйнувались, замість відносин, що базувались на принципах рівності i морального авторитету, виникли різні системи державної влади, щовзяли за основу насилля. Це стає однією з визначальнихознаклюдського співіснування.

Первинні уявлення про владу носили міфологічний характер. Синкретичне мислення стародавніх народів виходило $з$ того, що все, що відбувається на землі, $є$ відлунням більш загальних космічних процесів, отже влада, яка зосереджується у руках певного верховного правителя, або групи людей, дана 3 волі богів, має безапеляційну божественну санкцію. Посягання на таку владу розцінювалось як посягання на божественну волю, а отже намагання змінити верховну владу - це повстання проти самих володарів неба. Оскільки це так, повстання проти влади на ранніх етапах існування державних утворень придушувались з неймовірною жорстокістю.

У Стародавньому Світі вважалось, що влада має божественне походження, а верховний правитель країни (єгипетський фараон, цар Шумеру, китайський імператор) є не просто втіленням бога на землі, а живими богами, які спустились на землю і правлять людьми задля їх користі (Книга правителя области Шан (Шанцзюнь шу), 1993). Подібне ставлення до влади на початку цивілізації знайшло своє втілення у одному з головних принципів формування владних відносин у стародавньому світі, який красномовно виражено у Біблії: «Несть бо власть аще не от Бога: сущия же власти от Бога учинены суть» (Рим. 13. 1).

Зв'язок між земними та космічними порядками відчувався безпосередньо i тісно.Якщо людина підкорялась правителям своєї країни, виконувала вимоги державних законів, iї поведінка не тільки впливала на порядок у державі, але й забезпечувала гармонію у цілому космосі.

Сумніви щодо божественного походження влади виникли вже у глибокій давнині і пов'язані з багатьма обставинами. Верховні правителі держав як на Сході, так і на Заході, менш за все були заклопотані інтересами і потребами простого народу, якого розглядали радше як джерело доходів у казну держави. У ті часи владики не дуже розрізняли людей і робочу скотину, яку треба кормити і про яку треба піклуватись остільки, оскільки вона здатна працювати. Проте, коли умови життя ставали нестерпними, голод, вороже нашестя чи тягар влади ставили людей на межу життя i смерті, виникали бунти, і тоді ані війська, ані прокльони жерців, ані самі боги не могли зупинити доведених до відчаю народів. Бунтівники іноді досягали певних успіхів, і тоді авторитету влади завдавався найсильніший удар, іiі непохитність та вічність ставились під сумніви, виникала потреба переглядати вікові традиції та шукати нові форми владних стосунків. Соціальні обставини, що невпинно, хоча не дуже швидко, змінювались, диктували необхідність відступити від традиційних поглядів, щодо божественного походження влади, і шукати іiі земні корені. 
На межі VII-VI ст. ст. до н.е. 3'явились окремі особистості, які насмілились самостійно мислити, покладатись у пошуках істини не на зовнішній авторитет, а на свій розум, намагались самостійно знайти причини явищ природного i соціального оточення. У Стародавній Греції вони стали називати себе філософами. Вільні мислителі були не тільки у Стародавній Греції, а ще й у Індії та Китаї.

Китайський мудрець і філософ Конфуцій більшу частину життя присвятив тому, щоб зрозуміти, яким повинен бути найкращій державний устрій і яку роль у цьому грає морально досконала людина. Згідно з вченням Конфуція, влада верховного правителя у державі повинна базуватись, перш за все, на високому моральному авторитеті, бездоганності всього життя. Якщо це так, то такого правителя підвладні будуть всіляко поважати. Таким чином, вже Конфуцій започаткував принципи взаємодії між владарюючими і підвладними, що мають найвищою метою справедливість і гармонію у державі (Локк, 1988).

Особливої розмови щодо проблематики влади заслуговує Стародавня Греція. Ця невелика за розмірами країна відіграла визначну роль у формуванні європейського світобачення і європейської культури взагалі. «В усій історії людства, - писав Бертран Рассел, - нема нічого дивнішого й нез'ясованішого, ніж раптове постання цивілізації у Греції. Багато складників цивілізації вже цілі тисячоліття існувало в Сгипті й у Месопотамії і поширилися звідти у довколишні країни. Але деяких елементів бракувало, поки їх не внесли греки. Те, чого вони досягли у мистецтві і літературі, відоме будь-кому, але те, що вони створили у чисто інтелектуальній царині, ще винятковіше. Вони створили математику, науку взагалі і філософію; вони перші почали писати історію, а не просто літописи; вони вільно обговорювали природу і мету самого життя, не сковані кайданами ніякої традиційної ортодоксії» (Рассел, 1998, с. 20).

Перші грецькі філософи намагались зрозуміти природу. Але вже у Геракліта ми знаходимо певні філософські роздуми і узагальнення щодо суспільства, держави i влади. Його головна ідея полягала у тому, що владу повинні мати найкращі за моральними та розумовими якостями люди, а таких серед таких, що реально живуть, небагато. Правління у державі має спиратись на знання загальних законів космосу. Для більшості людей це $є$ недоступним. Більшість ніколи не може стояти на позиціях істини, оскільки істина, за визначенням, не приймається переважаючою кількістю особ. Один, наголошує філософ, є ціннішим, аніж десять тисяч, якщо він є найкращим. Отже найбільш правильною і ефективною формою влади $є$ влада одного, оскільки він найкращий у інтелектуальному і моральному плані, розуміє не тільки одиничне, але й всезагальне. Найкращим є той, хто «віддає перевагу не багатьом, а лише єдиному: вічній славі, а не смертним речам. Більшість же людей як тварини прагнуть до пересиченості» (Антология мировой философии, 1969, с. 280).

Цілком очевидно, що людей можна поділити на тих, хто живе високими потребами розуму і має гідність, і юрбу, що підкоряється інстинктам та задовольняється, переважно, тваринними потребами. Якщо влада буде у руках юрби, то це, на думку Геракліта, буде мати катастрофічні наслідки, призведе до загибель держави і людей, що iii населяють. Висновок наступний: влада має бути у руках найбільш гідних, тих, хто знає закони космосу і людського життя, має високі моральні якості і вміння керувати.

Торкаючись проблем влади, Сократ наголошував на тому, що для людей «найбільш важливим є доброчесність і справедливість, звичаї і закони» (Платон, Критон, 1999, с. 109). Будучи представником афінського демократичного полісу, Сократ невтомно переконував співгромадян у тому, що найкращим є життя відповідно до високих моральних принципів і правових законів. Тільки у цьому випадку спільне людське життя можна назвати справедливим, а ті, хто буде жити за цими законами, можуть називати себе цивілізованим народом, а не варварами. 
Найвищу владу повинні мати не люди, більшість чи меншість, а саме справедливість і закони, тобто загальні моральні і правові принципи. Люди у державі повинні розглядатися як рівні перед законами, незалежно від того, мають вони владу, чи ні. Такий висновок $є$ виключно важливим, оскільки $є$ однією з перших спроб логічно обгрунтувати необхідність переходу від влади, побудованої на насильстві до управління соціальними справами за допомогою раціональних і загальноприйнятих правил.

Платон піддає критиці давньогрецьку полісну демократію, а разом з тим і всі відомі йому на той час форми державного устрою, які, на його думку, є неправильними, тиранію, олігархію, плутократію (владу багатих), тимократію (владу військових), i пропонує свій проект ідеальної держави. На його думку, досконала держава - це така держава, де при владі стоять найкращі - аристократія. Державна влада у Платона повинна контролювати переважну більшість сфер суспільного життя, перш за все, виробництво і розподіл суспільних благ, захист держави від зовнішніх і внутрішніх ворогів, шлюб, народження та виховання дітей, тощо, не залишаючи ці сфери без постійного нагляду і контролю. Платон обмежує функції сім'ї, приватну власність, більшість форм самодіяльності людей та жанрів мистецтва. Ідеальна держава - це справедлива держава, а справедливість - це спроможність займатися своєю справою та не втручатися у чужі. Найвищим благом у суспільному житті, на думку Платона, $є$ благо держави.

«Мені здається, - розмірковує Платон, - що із тих властивостей держави, які ми розглянули, а саме розсудливість, мужність і мудрість, у держави є ще й остання властивість, яка тим попереднім дає можливість народитися 3 неї, а коли вони з'являються, вона забезпечує їм подальше буття доти, доки сама буде існувати. I ми стверджували, що залишок після того, як ми знайшли згадані три властивості, якраз i буде справедливістю... кожний робить щось своє і не втручатись до іншого» (Платон, Государство, 1999, с. 13).

Думка Платона щодо принципів державного устрою і організації влади, певною мірою, є кроком назад, у порівнянні з роздумами з цього приводу Сократа. Не закони, що розроблені на основі раціональних принципів, як вважав Сократ, а саме люди, які, на думку Платона, є найкращими, повинні мати всі важелі влади. Платон виказує повну недовіру демократії, - владі народу,- оскільки ця державна форма неодноразово демонструвала свою несправедливість відносно своїх найкращих громадян (страта Сократа - одна 3 них). А якщо вбивають і виганяють 3 батьківщини найкращих і їх місце заступають набагато гірші, то таку державу навряд чи можна назвати справедливою. Лейтмотивом роздумів Платона про ідеальну державу стає ідея виховання досконалих громадян, чим повинна, у першу чергу, займатись держава, ні в якому разі не пускаючи цей процес на самоплив. Якщо виховувати гідних людей, то можна покоління за поколінням покращувати людську породу і постійно знаходити найкращих для виконання суспільних функцій, серед яких керування державою $\epsilon$ найважливішою.

Здається, що аргументи Платона виглядають переконливими. Проте, його модель ідеальної держави насправді має суттєві вади, того, що було названо деспотизмом або тоталітаризмом [див.:15]. У сконструйованій ним моделі майже всі сторони життя контролює держава, повністю відсутня індивідуальна свобода. Щастя окремих людей видається несуттєвим поряд з щастям цілого - держави. Люди у платонівській державі - це гвинтики гігантської державної машини, мета якої - існуванні іiі самої. Хоча Платон, нібито, дбає про загальне щастя, проте на практиці сконструйована ним система влади веде до нерівності і привілеїв для обраних. Філософ не враховує (або навмисне ігнорує) такий важливий фактор, як свобода людини, iї ненаситна жага до 
творчості і самовдосконалення. Люди ніколи не погодяться бути цілком залежними від когось, хай його будуть звати «божественним правителем». А тому «ідеальна держава» Платона приречена на всенародний бунт, оновлення або знищення.

Багато праць, присвячених всебічному дослідженню проблематики влади маємо у Аристотеля. Зокрема, у роботі «Політика» відправною точкою аналізу виступає поняття спілкування, тобто той факт, що люди є колективними істотами. «Будь-яка держава, писав античний мислитель, -є певним спілкуванням», яке «організовується заради якого-небудь блага» (Аристотель, 1981, с. 376).

Своєрідність державного спілкування, пояснює Аристотель, полягає у тому, що воно «є найбільш важливим з усіх і обіймає собою усі інші спілкування» (Аристотель, 1981, с. 376). Його особливість полягає у тому, що воно вимагає певної організації, встановлення спеціальних інститутів. «У всіх людей, - зауважує Аристотель, - природа вселила прагнення до державного спілкування, i перший, хто це спілкування організував, зробив людству найбільше благо» (Аристотель, 1981, с. 376). Мова йде про того, хто зміг організувати усіх в одну спільноту, одну цілісність, ім'я якої держава. Отже, оскільки люди $є$ розумними істотами, вони створюють державу цивілізований і справедливий спосіб сумісного спілкування.

Якщо людина позбавлена розумових і моральних якостей, вона, на думку філософа, виявляється дикою істотою, здатною здійснювати лише несправедливість, як у спілкуваннях одиничного характеру, так і у справі організації державного спілкування людей. Загального блага неможливо досягти за допомогою несправедливої організації людей. Відсутність загального блага свідчить про відсутність держави. Цивілізоване співіснування неминуче скачується у варварство, крізь яке просвічує тваринна природа стадності, при збереженні видимості державності, якщо порушується загальний закон природи - гармонія владного і підвладного начал.

Римська держава за тисячолітню історію свого існування пережила різні форми державного устрою: царська влада, республіка, абсолютистська влада імператорів. Ця історія переповнена безліччю подій, пов'язаних з боротьбою за владу, вона дає більш ніж достатньо фактів для філософських узагальнень.

Римський філософ і політичний діяч Цицерону своїх роздумах щодо найкращого політичного устрою суспільства значне місце приділяв проблемам влади. «Що таке держава, - зауважував Цицерон, - як не надбання народу?...А що таке громадянська община, як не безліч людей, пов'язаних певною згодою»? (Цицерон, 2019, с. 18). Торкаючись питання про виникнення держави, філософ наголошував, що «не будь у людини зародків справедливості, не виникло б ані доблесті, ані самої держави» (Цицерон, 2019, с. 18).

Цицерон стверджував: «будь-який народ, що є об'єднанням багатьох людей...будьяка громадянська община, що є народним встановленням, будь- яка держава, яка... $є$ народним надбанням, щоб бути довговічними, повинні управлятися... радою, а рада ця повинна виходити передусім з тієї причини, яка породила громадянську общину. Здійснення їх слід доручати або одній людині, або декільком виборним або ж його повинно на себе брати безліч людей, тобто усі громадяни. I ось, коли верховна влада знаходиться у руках однієї людини, ми називаємо цього одного царем, а такий державний устрій - царською владою. Коли вона знаходиться у руках у виборних, то говорять, що ця громадянська община управляється волею оптиматів. Народною ж $є$ така община, в якій усе знаходиться у руках народу. I кожен з трьох видів держави якщо тільки зберігається той зв'язок, який уперше дуже міцно об'єднав людей зважаючи на їх загальну участь у створенні держави, - правда, не досконалий i, на мою думку, не найкращий, але він все ж терпимий, хоча один 3 них може бути краще іншого. Бо положення і справедливого і мудрого царя, і обраних, тобто тих, хто $є$ 
першими, громадян, і навіть народу (втім, останнє найменше заслуговує схвалення) все ж, - якщо тільки цьому не перешкоджають несправедливі вчинки або пристрасті, очевидно, може бути цілком міцним» (Цицерон, 2019, с. 19).

Середньовіччя являє собою приклад суперечливої i трагічної практики застосування влади у людських спільнотах. 3 одного боку, проголошувалось, що влада будь-якого короля, царя чи імператора дана йому самим Богом, який за визначенням $\epsilon$ добрим і справедливим. Оскільки це так, володар мав би піклуватись про тих, ким править. 3 іншого боку, влада королів і пап у християнській Свропі супроводжувалась кривавими потоками насилля, війн, завоювань чужих земель, незчисленних жертв, винищення цілих країн і народів. Розбещеність світської і церковної влади не знала меж, іii дії - це нескінченна кількість таких, що не піддаються ніякому опису моральних збочень і кримінальних злочинів, які не мали нічого спільного ані 3 людськими законами, ані 3 божими. При цьому, нескінченне насилля супроводжувалось цинічним лицемірством і обманом: нібито така ситуація є розплатою за людські гріхи.

Новий час став переломною епохою у житті цивілізованих народів Європи у багатьох сенсах. Це був час, коли темрява ночі невігластва, мракобісся і страшних релігійних забобонів почала поступово поступатися місцем світлу знання і розуму. Проте пряме насилля з боку влади продовжувалось. Однак тепер воно викликало не тільки страх, але й протест, жагу до справедливості і свободи, яка спочатку народилась в осередках освічених людей, а далі оволоділа умами більшості народу.

Досліджуючи проблеми війни та миру і торкаючись, у цьому зв'язку питання влади, Г. Гроцій писав: «Верховною владою називається така влада, дії якої не підпорядковані іншій владі і не можуть бути скасовані чужою владою на іï розсуд... Носій iї може бути або у загальному, або ж у власному сенсі; подібно до того як загальним носієм зору є тіло, власний же - це око, так загальним носієм верховної влади є держава... Носієм влади у власному сенсі $є$ або одна особа, або ж декілька, згідно законам і устоям того або іншого народу» (Гроций, 1994, с. 158).

Гроцій задавався питанням, чи може верховна влада належати народу? Його точка зору з цього приводу однозначна: «Слід... відкинути думку тих, хто вважає, що верховна влада усюди і без вилучення належить народу, так що государів, які зловживають своєю владою, слід позбавляти влади і карати; ця думка, проникнувши у глибину душі, послужила і може послужити ще надалі причиною настільки багатьох лих, що не може сховатися від кожного, хто обдарований розумом» (Гроций, 1994, с. 158). Філософ зауважує, що дехто обстоює ту тезу, що «будь який уряд заснований заради тих, ким управляє, а не заради тих, хто управляє; тому, як вважають, з гідності самої мети виходить, що керовані вище за правителів» (Гроций, 1994, с. 164). Таке положення абсолютно не відповідає істині; воно стосується, скоріше, того, що мало б бути, а не того, що є насправді. Можна навести безліч прикладів, коли уряди існують не заради народу, а заради правителя і самих себе. Разом з тим, Гроцій погоджується 3 аргументами тих, хто стверджував, що «у більшості держав метою самою по собі $є$ користь самих підвладних; вірно те, що сказано Цицероном услід за Геродотом, а Геродотом услід за Гесіодом, а саме, що царі встановлені для здійснення справедливості» (Гроций, 1994, с. 165).

Томас Гоббс пояснює виникнення влади і держави природним прагненням людей до безпеки. Таку безпеку ніщо не може гарантувати людині, якщо вона перебуває у природному стані, оскільки покладання на власні сили є фактором вкрай ненадійним. Життя людини у природному стані надзвичайно важке, оскільки немає взагалі ніяких гарантій ані на плоди власної праці, ані на життя взагалі. У людей, які живуть поза державним станом, «Немає землеробства, судноплавства, морської торгівлі, зручних 
будівель, немає засобів руху і пересування речей, що вимагають великої сили, немає знання земної поверхні, числення часу, ремесла, літератури, немає суспільства, а, що найгірше, $є$ вічний страх і постійна небезпека насильницької смерті, і життя людини самотне, бідне, безпросвітне, тупе і короткочасне» (Гоббс, 1989, с. 65)

Проте, згідно з основним природним законом, «у разі згоди на те інших, людина повинна погодитись відмовитись від права на всі речі у тій мірі, в якій це необхідно в інтересах миру і самозахисту, і задовольнятися таким ступенем свободи по відношенню до інших людей, який вона припускала б в інших людей по відношенню до себе» (Гоббс, 1989, с. 99). Гоббс уточнює, що немає ніяких підстав відмовлятися від цього права, якщо інші люди не готові зробити те ж саме, оскільки це означатиме швидше добровільну згоду на розграбування чим схильність до миру.

Природні закони, незважаючи на свою уявну непохитність, можуть порушуватися. Філософ застерігає, що «самі по собі, без страху перед якоюсь силою, що примушує їх дотримуватися, суперечать природним потягам, що тягнуть нас до пристрасті, гордості, мести і т. ін. А угоди без меча - це лише слова, які не в силах гарантувати людині безпеку» (Гоббс, 1989, с. 129). За Гоббсом, там, де відсутня надійна влада, що спирається на силу, і у змозі гарантувати людям безпеку, кожна людина може на законних підставах використати свою силу для того, щоб убезпечити себе від усіх інших людей. Саме у державі може бути встановлена така влада.

Монарх або загальні збори людей є ядром держави, яку Гоббс визначає єдиною особою, «відповідальність за дії якої настає завдяки взаємному договору між величезною безліччю людей, з тим, щоб ця особа могла використати силу і засоби усіх їх так, як визнає за необхідне, для забезпечення миру і загального захисту» (Гоббс, 1989, с. 133). При цьому, засоби для їх досягнення залишаються повністю на розсуд володаря. Іншими словами, мета виправдовує будь-які засоби.

Політична влада, згідно поглядам Джона Локка, визначається «правом створювати закони, що передбачають страту і відповідно усі менш суворі заходи покарання для регулювання і збереження власності, і застосовувати силу спільноти для виконання цих законів для захисту держави від нападу ззовні - і усе це тільки заради загального блага» (Гоббс, 1989, с. 263).

Локк стверджує, що усі люди залишаються у природному стані до тих пір, поки за власною згодою не стають членами певного політичного суспільства.

Локк не поділяє погляди Гоббса, що природний стан і стан війни є тотожними. Головна причина, за якою люди утворюють суспільство i відмовляються від природного стану - це прагнення уникнути стану війни, коли вже стираються усі відмінності і не існує ніякої влади, яка винесла б ухвали тим, що сперечається. «Адже коли є яка-небудь влада, яка-небудь сила на землі, від якої можна отримати допомогу, якщо до неї звернутися, то продовження стану війни виключається і суперечка вирішується цією владою» (Гоббс, 1989, с. 274)

Торкаючись проблем державної влади, Кант писав: «Держава є об'єднанням множини людей, що підкоряються правовим законам» (Кант, 1965, с. 233). Це визначення має на увазі ідею держави, або державу, якою їх належить бути. Такі, що реально існують, держави можуть лише у тій або в іншій мірі наближатись до цього ідеалу. За Кантом, держава 3 необхідністю повинна мати три види влади: «верховна влада (суверенітет) у особі законодавця, виконавча влада у особі правителя (правлячого згідно із законом) і судова влада (що присуджує кожному своє згідно із законом) у особі судді (potestas legislatoria, rectoria etiudiciaria), як би три судження у практичному силогізмі: велика посилка, що містить у собі закон загальним чином об'єднаної волі; менша посилка, що містить у собі веління поступати згідно із законом, тобто, принцип 
підведення під цю волю, і висновок, що містить у собі судове рішення (вирок) відносно того, що у даному випадку відповідає праву» (Кант, 1965, с. 234).

Послідовно проводячи принципи своєї філософії при аналізі природних, суспільних і духовних явищ, Гегель обстоює ту думку, що досконала держава - це така держава, де на практиці реалізується принцип єдності одиничного, особливого i загального (Гегель, 1990, с. 229). 3 цієї точки зору, недолік «ідеальної держави» Платона полягав в тому, що тут панує принцип загального і ігноруються особливе і одиничне. По суті, модель держави, сконструйована Платоном, з самого початку була ущербною, оскільки свідомо не враховувались особливі потреби громадян, їх індивідуальна свобода. Прагнення до тотальності, змусило Платона удатися до абсолютно фантастичних допущень про можливість скасування в «ідеальній державі» таких важливих соціальних інститутів, як сім'я і приватна власність, що суперечило всьому тому, що показує людська історія. Напроти, якщо дається необмежений простір одиничному, тобто стихії індивідуальних потреб і цілей, то це веде до катастрофічних наслідків: держава та й людська спільнота взагалі руйнуються.

Хоча теорія держави Аристотеля відрізняється від концепції Платона суттєвими деталями, за Гегелем, вона також являє собою приклад однобічності, а саме, - примат загального над одичним.

Виходячи 3 цих міркувань, влада, що зупиняється на одній із сторін розглядуваного феномену, забуваючи або навмисно ігноруючи інші, $\epsilon$ за визначенням негативною владою. Державна влада, що відповідає своєму поняттю, представляє собою діалектичну єдність одиничного, особливого і загального. Така влада виступає надійним інструментом розвитку суспільства, забезпечує гармонійне поєднання одиничних інтересів окремих громадян і загального блага.

Підводячи підсумки, необхідно відзначити наступне. У межах класичної філософської думки було розроблено важливі принципи функціонування влади у суспільстві та засоби, що забезпечують іiї ефективність. 3'ясовано, що владні стосунки супроводжують людину як колективну істоту упродовж усієї іï історії, є незмінним атрибутом соціального життя. Будучи успадкованими від своїх тваринних предків, вони отримали найрізноманітніші форми у ранніх людських спільнотах, виконуючи як конструктивну, так і деструктивну роль. Вододілом між вказаними проявами влади $\epsilon$ виконання нею своїх головних функцій, серед яких чи на найпершому місці стоїть керування суспільними процесами, забезпечення сталого розвитку людських спільнот. За традицією, владою зі знаком «плюс» називали таку владу, яка приносить благо більшій частині або усім членам певної спільноти. Негативна влада - це така влада, яка має метою благо обмеженого кола обраних або навіть одного верховного правителя, i, у кінцевому підсумку, руйнує соціальну тканину суспільства. Питання щодо співвідношення цілей і засобів, якими влада домагається виконання своїх вимог, має тут вирішальне значення.

Упродовж майже всієї людської історії можна спостерігати тісний зв'язок між владою і насильством. Іноді здається, що воно взагалі є неусувним з людського життя, ледве чи визначальний чинник людських стосунків. Саме по собі насильство мало у кого знаходить відверте схвалення. Більшість філософів, та й взагалі пересічних людей, як правило, його засуджують. Класична філософська думка обгрунтовано доводить, що для розумних істот, якими вважають себе люди, більш прийнятними впровадження владних рішень $\epsilon$ не насильство, а моральний авторитет і право. Саме право у такому, що все більш ускладнюється, людському суспільстві, поступово стає пріоритетним інструментом влади.

Влада завжди прагне зберегти себе як можна довше, у граничному плані - стати вічною. Проте є багато причин об'єктивного і суб'єктивного характеру, що ставлять 
межу таким намаганням. Людське суспільство - це виключно складна система зв'язків і відносин. Ефективна робота цієї системи забезпечується, у тому числі, ефективними управлінськими рішеннями, а також тісним зв'язком між прийнятими рішеннями i їх виконанням. Тобто, - саме владними відносинами. Хочемо ми цього чи не хочемо, але у суспільстві завжди будуть керівники і підлеглі, ті, хто приймає рішення, i ті, хто повинен їх виконувати, тобто, владарюючі і підвладні. Від того, наскільки будуть ефективними рішення, і наскільки успішно вони будуть впроваджуватись у життя,

залежить успішне функціонування різних людських спільнот, майбутнє загальнолюдського суспільства взагалі. Саме це, в ідеальному варіанті, повинна забезпечувати влада.

\section{СПИСОК ВИКОРИСТАНИХ ДЖЕРЕЛ}

Антология мировой философии. Ч. 1. Филофософия древности и средневековья. (1969). Москва: Мысль.

Аристотель. (1981). Политика (Т. 3). Москва: Мысль.

Библия. Книги Священного Писания Ветхого и Нового завета. (1995). Москва: Библейские общества.

Гегель, Г. В. (1990). Философия права. Москва: Мысль.

Гоббс, Т. (1989). Левиафан или материя, форма и власть государства иерковного и гражданского (Т. 2). Москва: Мысль.

Гроций, Г. (1994). О праве войны и мира. Москва: Ладомир.

Кант, И. (1965). Метафизика нравов в двух частях (Т. 4). Москва: Мысль.

Кейзеров, Н. М. (1973). Власть и авторитет. Москва: Юридическая литература.

Книга правителя области Шан (Шанщзюнь шу). (1993). Москва: Ладомир.

Конфуций. (2000). Уроки мудрости. Сочинения. Харьков: Фолио.

Локк, Д. (1988). Два трактата о правлении (Т. 3). Москва: Мысль.

Панарин, А. С. (2000). Политология. Западная и восточная традиция. Москва: Книжный дом «Университет».

Платон. (1999). Государство. В Платон. Филеб. Государство. Тимей. Критий (стр. 79-420). Москва: Мысль.

Платон. (1999). Критон. В Платон. Апология Сократа. Критон. Ион. Протагор (стр. 97-111). Москва: Мысль.

Поппер, К. (1992). Открытое общество и его враги. В Кн. 1. Чары Платона (стр. 448). Москва: Мысль.

Рассел, Б. (1998). История западной философии. Ростов-на-Дону: Феникс.

Тоффлер, Э. (2003). Метаморфозы власти. Москва: АСТ.

Халипов, В. Ф. (1999). Кратология как система наук о власти. Москва: Республика.

Цицерон. (25 122019 г.). Диалоги. О государстве. О законах. Получено из http://ancientrome.ru/

Weber, M. (1922). Wirtschaft und Gesellschaft. Tubingen.

\section{МЕТАФИЗИКА ВЛАСТИ: КЛАССИЧЕСКИЙ ФИЛОСОФСКИЙ ДИСКУРС}

\footnotetext{
Аннотация. В рамках классической философской мысли был разработан важные принципы функционирования власти в обществе и средства, обеспечивающие ее
} 
эффективность. Выяснено, что властные отношения сопровождают человека как коллективную существо на протяжении всей ее истории, является неизменным атрибутом социальной жизни. Будучи унаследованными от своих животных предков, они получили самые разнообразные формы в ранних человеческих сообществах, выполняя как конструктивную, так и деструктивную роль. Водоразделом между указанными проявлениями власти является выполнение ею своих основных функций, среди которых или на самом месте стоит управления общественными процессами, обеспечение устойчивого развития человеческих сообществ. По традиции, властью со знаком «плюс» называли такую власть, которая приносит благо большей части или всех членов определенного сообщества. Негативная власть - это такая власть, которая имеет целью благо ограниченного круга избранных или даже одного верховного правителя, и, в конечном итоге, разрушает социальную ткань общества. Вопрос о соотношении целей и средств, которыми власть добивается выполнения своих требований, имеет решающее значение. Классическая философская мысль обоснованно доказывает, что для разумных существ, которыми считают себя люди, более приемлемыми внедрения властных решений является не насилие, а моральный авторитет и право. Именно право в таком все более усложняется, человеческом обществе, становится приоритетным инструментом власти..

Ключевые слова: власть, философия власти, властные отношения, метафизика власти.

\section{THE METAPHYSICS OF POWER: A CLASSICAL PHILOSOPHICAL DISCOURSE}

Abstract. In the framework of classical philosophical thought important principles of functioning of power in society and means ensuring its effectiveness were developed. It is found out that power relations accompany a person as a collective person during the whole of its history, is an invariable attribute of social life. Having been inherited from their animal ancestors, they took many forms in early human communities, playing both constructive and destructive roles. The division between the mentioned manifestations of power is its main functions, among which or on the very place is the management of social processes, ensuring the sustainable development of human communities. Traditionally, power with the sign "plus" was called such power, which brings benefit to the greater part or all members of a certain community. Negative power is power that aims to benefit a limited number of elected or even one supreme ruler, and ultimately destroys the social fabric of society. The question of the relationship between the goals and means with which the power seeks to fulfill its demands is crucial. Classical philosophical thought justifiably proves that for sentient beings, who people consider themselves to be, the more acceptable introduction of power decisions is not violence, but moral authority and right. It is the right in human society, which is becoming more and more complex, that is becoming the priority instrument of power. Throughout almost the entire human history, one can observe a close connection between power and violence. Sometimes it seems that it is not removable from human life at all, is almost a determining factor in human relations. In itself, violence is not very well received by anyone. Most philosophers, and ordinary people in general, tend to condemn it. Power always strives to preserve itself as long as possible, in the ultimate plan - to become eternal. However, there are many reasons of an objective and subjective nature that set the edge of such attempts. Human society is an extremely complex system of connections and relations. The effective work of this system is ensured, among others, by effective managerial decisions, as well as by the close connection between the decisions made and their implementation. In other words, it is through power relations. Whether we want it or not, there will always be managers and subordinates in society, those who make decisions and those who have to implement them, i.e. those who are in power and subject to them. The successful functioning of various human communities and the future of human society as a whole depend on how effective decisions will be and how successfully they will be implemented in life. This, ideally, is what power should provide.

Keywords: power, philosophy of power, power relations, metaphysics of power. 